\title{
IL-35 Inhibits Angiogenesis through VEGF/Ang2/Tie2 Pathway in Rheumatoid Arthritis
}

\author{
Shenyi Jiang Yuxuan Li Tiantian Lin Lin Yuan Yunxia Li Suqin Wu Liping Xia \\ Hui Shen Jing Lu
}

Department of Rheumatology and Immunology, the First Affiliated Hospital of China Medical University, Shenyang, PR China

\section{Key Words}

IL-35 • Rheumatoid arthritis • Angiogenesis • Ang2 • Tie2

\begin{abstract}
Background/Aims: The pro-angiogenic factors vascular endothelial growth factor (VEGF) and angiopoietins (Angs) play a prominent role in synovial angiogenesis, an early and critical event in the pathogenesis of rheumatoid arthritis (RA). Interleukin (IL)-35 is an anti-inflammatory cytokine that attenuates collagen-induced arthritis, however, the mechanisms involved are not fully understood. Methods: The effects of IL-35 on endothelial cell migration, adhesion, and tube formation were examined using human umbilical vein endothelial cells (HUVEC) in vitro. The effects of IL-35 on vessel formation in vivo were examined using a murine Matrigel plugs model. MMP2/MMP9 and IL-6/IL-8 secretion were assessed by zymography and ELISA, respectively. The crosstalk between IL-35, VEGF, and Ang2 in HUVECs and RA synovial tissue explants was investigated. Results: IL-35 inhibited basal and VEGF-induced HUVEC migration and adhesion in vitro as well as tube formation in vitro and in vivo. VEGF increased Ang2 secretion by HUVECs and RA synovial tissue explants, and exogenous Ang2 promoted HUVEC migration, adhesion, and tube formation with similar potency to VEGF. Blocking the Ang/Tie2 pathway with a Tie2 kinase antibody inhibited the proangiogenic effects of exogenous Ang2 and VEGF in HUVECs. IL-35 inhibited basal and VEGF-induced Ang2 secretion by HUVECs and RA synovial tissue explants; it also antagonized the proangiogenic effects of exogenous Ang2 in HUVECs. Moreover, IL-35 reduced basal and VEGF/Ang2-induced MMP2/MMP9 and IL-6/ IL-8 secretion. Conclusion: These results suggested that IL-35 restrains RA angiogenesis and inflammation by downregulating basal and VEGF-induced Ang2 secretion as well as disrupting Ang2/Tie2 signal transduction. Our findings extend current understanding of mechanisms regulating RA angiogenesis and may support development of novel angiogenesis-targeting therapeutics for RA treatment.
\end{abstract}




\section{Cellular Physiology Cell Physiol Biochem 2016;40:1105-1116 \begin{tabular}{l|l|l} 
and BiOChemistry & $\begin{array}{l}\text { DOI: 10.1159/000453165 } \\
\text { Published online: December 14, } 2016\end{array}$ & $\begin{array}{l}\text { C } 2016 \text { The Author(s). Published by S. Karger AG, Basel } \\
\text { www.karger.com/cpb }\end{array}$
\end{tabular} \\ Jiang et al.: The Inhibitory Role of IL-35 in Angiogenesis}

\section{Introduction}

Synovial angiogenesis is a critical early event in rheumatoid arthritis (RA), fostering pannus formation, persistent leukocyte infiltration, and lining layer hyperplasia, leading to cartilage and bone destruction [1,2]. RA angiogenesis is driven and maintained by proangiogenic factors released from RA synovial tissue myeloid cells and fibroblasts, which include vascular endothelial growth factor (VEGF), angiopoietin (Ang)1 and 2, plateletderived growth factor, and transforming growth factor- $\beta$ [3-5]. VEGF is the most potent proangiogenic factor in RA angiogenesis, highly expressed in RA [6], stimulating endothelial cell (EC) proliferation, migration, and vascular tube formation [7]. The EC specific factors Ang1 and Ang2 and their tyrosine kinase receptors Tie 1 and Tie 2 are also critical in normal and pathological vascular development [8, 9]. Ang1, Ang2, Tie1, and Tie2 are upregulated in RA synovial tissues [10]. Evidence suggests that the Ang/Tie2 signaling pathway mediates the proangiogenic effects of tumor necrosis factor alpha (TNF- $\alpha$ ), interleukin (IL)-6, and tolllike receptor (TLR)2 in RA $[5,11,12]$. Ang2 neutralization decreases synovial inflammation, neovascularization, and joint destruction in CIA [13]. Higher synovial Tie2 activation in RA patients has prognostic power for the development of erosive disease [14]; Tie2 blockade inhibits the onset, incidence, and severity of CIA and protects against bone destruction [15]. These findings underscore the significance of this pathway in RA angiogenesis and disease progression.

IL-35 is an anti-inflammatory cytokine of the IL-12 cytokine family that also includes IL12 , IL-23, and IL-27. It is a heterodimer of the IL-27 $\beta$ and IL-12 $\alpha$ chains, which are encoded by the Epstein-Barr virus-induced gene 3 (EBI3) and IL12A genes, respectively $[16,17]$. IL35 is primarily produced by regulatory T cells (Tregs) and signals via binding to IL-12R $\beta 2$ / gp130 heterodimers or gp130 and IL-12R $\beta 2$ homodimers, leading to activation of the JAKSTAT pathway [18]. IL-35 supports expansion of CD $4^{+} \mathrm{CD} 25^{+}$Tregs, increases their inhibitory function, and induces a new set of Tregs called inducible IL-35-producing Tregs [16, 19, 20]. In contrast to "house-keeping" anti-inflammatory cytokines such as transforming growth factor beta (TGF- $\beta$ ), which are constitutively expressed and inhibit inflammation initiation, IL-35 is induced in response to inflammatory stimuli and suppresses inflammation in full-blown stage [21]. IL-35 curbs the development of various inflammatory syndromes in experimental models [16, 22-24]. In particular, IL-35 effectively attenuates clinical manifestation of CIA, and these anti-CIA effects are accredited to the stimulation of regulatory $\mathrm{T}$ cells, suppression of Th17 cells, and induction of IL-10 [22, 23].

Interestingly, recent studies have shown that IL-35 inhibits LPS-induced EC activation by suppressing the MAPK-AP-1 pathway [25]. Additionally, IL-35 has been reported to stimulate tumorigenesis by promoting tumor angiogenesis [26]. Therefore, we speculated that IL-35 might also play a role in synovial angiogenesis in RA. In this study, we examined the effects of IL-35 on basal and VEGF-induced human umbilical vein endothelial cell (HUVEC) migration and adhesion as well as tube formation in vitro and in vivo. The effects of IL-35 on matrix metalloproteinase and inflammatory cytokine secretion were also examined. The crosstalk between IL-35, VEGF, and Ang2 in HUVECs and RA synovial tissue explants was investigated. Our results revealed that IL-35 inhibited basal and VEGF-induced angiogenesis and inflammation, and these effects were mediated through inhibition of Ang2 expression and disruption of Ang2/Tie2 signal transduction.

\section{Materials and Methods}

\section{Cell culture}

Human umbilical vein endothelial cells (HUVECs) were purchased from American Type Culture Collection (ATCC). The cells were cultured in endothelial growth medium from Clonetics (San Diego, CA, USA) under $5 \% \mathrm{CO}_{2}, 37^{\circ} \mathrm{C}$ in a humidified incubator. Cells at early passages (3-7) were grown to $80 \%$ confluence and used in the in vitro studies. 


\section{Cellular Physiology Cell Physiol Biochem 2016;40:1105-1116 \begin{tabular}{ll|l} 
and Biochemistry $10.1159 / 000453165$ & $\begin{array}{l}\text { (c) } 2016 \text { The Author(s). Published by S. Karger AG, Basel } \\
\text { www.karger.com/cpb }\end{array}$
\end{tabular}}

Jiang et al.: The Inhibitory Role of IL-35 in Angiogenesis

Wound healing migration assay

HUVEC migration in vitro was measured using the wound healing assay. Briefly, HUVECs were seeded in $60 \mathrm{~mm}$ culture dishes and grown to $80 \%$ confluence. The medium was replaced with fresh medium containing $20 \mathrm{ng} / \mathrm{ml} \mathrm{VEGF}_{165}$ and various concentrations of IL-35 (0-40 ng/ml). PBS was used as vehicle control for both $\mathrm{VEGF}_{165}$ and IL-35. Immediately after the medium exchange, a scratch was created with a pipette tip. After $18 \mathrm{~h}$ incubation, images ( $\times 100$ magnification) were captured, and cell migration was quantified by counting the cells that had moved beyond the reference line. In mechanism studies, cells grown to $80 \%$ confluence were placed in fresh medium containing $20 \mathrm{ng} / \mathrm{ml} \mathrm{VEGF}_{165}, 200 \mathrm{ng} / \mathrm{ml} \mathrm{Ang2,40}$ $\mathrm{ng} / \mathrm{ml} \mathrm{IL-35}$, and $10 \mu \mathrm{g} / \mathrm{ml}$ anti-Tie2 antibody or anti-IgG control, in combination or alone. A scratch was created and migration was determined after $18 \mathrm{~h}$ incubation as above. Each experiment was conducted in triplicate. Human recombinant VEGF ${ }_{165}$ (\#8065) was purchased from Cell Signaling Technology (Beverly, MA, USA). IL-35 (ALX-522-140-C010) and Ang2 (ENZ-PRT162-0010) were obtained from Enzo Life Sciences (Farmingdale, NY, USA). Anti-Tie2 antibody and anti-IgG control were from R\&D systems (Minneapolis, MN, USA).

\section{Chemotactic migration assay}

The chemotactic migration of HUVECs was measured using a Transwell chamber with 6,5 mm polycarbonate membranes ( $8 \mu \mathrm{m}$ pore size) pre-coated with BD Matrigel ${ }^{\mathrm{TM}}$ Basement Membrane Matirx (BD Bioscience, San Jose, CA, USA). HUVECs were incubated in serum free endothelial growth medium without growth factors for $2 \mathrm{~h}$ before use. Fresh medium containing $20 \mathrm{ng} / \mathrm{ml} \mathrm{VEGF}_{165}$ was added to the lower chambers. PBS was used as vehicle control for VEGF ${ }_{165}$. HUVECs were trypsinized and suspended in fresh medium containing various concentrations of IL-35 (0-40 ng/ml). The cells were loaded at $2 \times 10^{4}$ cells/well to the upper chambers and allowed to migrate for $4 \mathrm{~h}$ at $37^{\circ} \mathrm{C}$. The cells were subsequently fixed and stained with hematoxylin and eosin. Non-migrating cells on the upper surface of the membrane were removed using a cotton swab. The cells that had migrated to the lower surface of the membrane were counted under a microscopy at $\times 200$ magnification. Cells in eight randomly selected fields of each membrane were counted. Each experiment was conducted in triplicate. In mechanism studies, fresh medium containing $20 \mathrm{ng} / \mathrm{ml}$ $\mathrm{VEGF}_{165}$ and $200 \mathrm{ng} / \mathrm{ml}$ Ang2, in combination or alone was added to the lower chambers. Cells suspended in fresh medium containing $40 \mathrm{ng} / \mathrm{ml} \mathrm{IL-35,} 10 \mu \mathrm{g} / \mathrm{ml}$ anti-Tie2, or $10 \mu \mathrm{g} / \mathrm{ml}$ anti-IgG control were loaded to the upper chambers. Chemotactic migration was measured as described above.

\section{Cell adhesion assay}

HUVECs $\left(5 \times 10^{4}\right.$ cells $\left./ \mathrm{ml}\right)$ were seeded in fibronectin (FN)-coated 96-well plates. Cells seeded in bovine serum albumin (BSA)-coated plates were used as negative control. After $24 \mathrm{~h}$ incubation, cells in FN-coated plates were treated with $20 \mathrm{ng} / \mathrm{ml} \mathrm{VEGF}_{165}$ in the presence of various concentrations of IL-35 (0$40 \mathrm{ng} / \mathrm{ml}$ ) for $24 \mathrm{~h}$. PBS was used as vehicle control for both $\mathrm{VEGF}_{165}$ and IL-35. After treatment, cells were washed twice with PBS, and $200 \mu \mathrm{l}$ of fresh medium containing $5 \%$ fetal bovine serum (FBS) and $10 \%$ (v/v) MTS reagent were added to the cells. Absorbance at $490 \mathrm{~nm}$ was recorded on a microplate reader. Each experiment was conducted in triplicate. In mechanism studies, cells in FN-coated plates were treated for $24 \mathrm{~h}$ with $20 \mathrm{ng} / \mathrm{ml} \mathrm{VEGF}_{165}, 200 \mathrm{ng} / \mathrm{ml} \mathrm{Ang2,} 40 \mathrm{ng} / \mathrm{ml} \mathrm{IL-35,} \mathrm{and} 10 \mu \mathrm{g} / \mathrm{ml}$ anti-Tie2 or anti-IgG control, in combination or alone. After treatment, cell adhesion was determined using the MTS assay as described above.

\section{Tube formation assay}

HUVEC tube formation was examined as described previously [27]. Briefly, HUVECs $\left(2 \times 10^{4}\right.$ cells $\left./ \mathrm{ml}\right)$ were seeded in Matrigel-coated 96-well plates and incubated with $20 \mathrm{ng} / \mathrm{ml} \mathrm{VEGF}$ in in the presence of various concentrations of IL-35 (0-40 ng/ml) for $18 \mathrm{~h}$. PBS was used as vehicle control for both VEGF ${ }_{165}$ and IL-35. After incubation, the formation of capillary-like structures was analyzed by phase contrast microscopy. Each experiment was conducted in triplicate. In mechanism studies, HUVECs seeded in Matrigel-coated plates were incubated for $18 \mathrm{~h}$ with $20 \mathrm{ng} / \mathrm{ml} \mathrm{VEGF}_{165}, 200 \mathrm{ng} / \mathrm{ml} \mathrm{Ang} 2,40 \mathrm{ng} / \mathrm{ml} \mathrm{IL-35}$, and $10 \mu \mathrm{g} / \mathrm{ml}$ antiTie2 or anti-IgG control, in combination or alone. The formation of capillary-like structures was analyzed by phase contrast microscopy. 


\section{Cellular Physiology Cell Physiol Biochem 2016;40:1105-1116

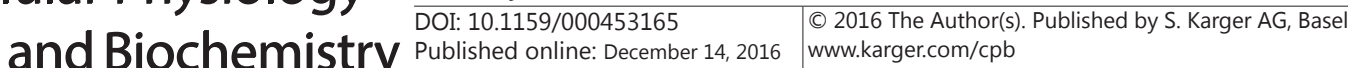 \\ Jiang et al.: The Inhibitory Role of IL-35 in Angiogenesis}

\section{Matrigel plug assay}

All animal experiments were approved by the Animal Experimentation Ethics Committee of the First Affiliated Hospital of China Medical University (Shenyang, China) and carried out in compliance with the Principles of Laboratory Animal Care (National Society for Medical Research). C57BL/6 mice were obtained from the Animal Experiment Center of Chinese Academy of Sciences (Shanghai, China). Matrigel (500 $\mu$ l) containing $\mathrm{VEGF}_{165}(500 \mathrm{ng} / \mathrm{ml})$ and heparin $(9 \mathrm{U} / \mathrm{ml})$ was subcutaneously injected with or without IL-35 $(2 \mu \mathrm{g})$ into the abdomen of C57BL/6 mice (4-6 weeks of age). PBS was used as negative control for both $\mathrm{VEGF}_{165}$ and IL-35. Six mice were included in each treatment group. After 14 days, mice were sacrificed. Matrigel plugs were carefully dissected out. Surrounding connective tissues were removed. Hemoglobin (Hb) levels were measured by the Drabkin method using the Drabkin reagent kit 525 from Sigma (St. Louis, MO, USA). For histological analysis of vascularity, plugs were fixed in $4 \%$ formalin, embedded in paraffin, and stained with hematoxylin and eosin.

$R A$ synovial tissue explant culture

To examine Ang2 production by RA synovial tissues, we used an ex vivo RA synovial tissue explant model, which closely mimics the in vivo RA synovial microenvironment [28]. RA synovial tissue explants were collected as surgical waste from individuals undergoing elective RA surgery with informed consent of the patient. The tissues were sectioned into $1 \mathrm{~mm}$ cubes, placed in 96-well plates in RPMI 1640 supplemented with streptomycin $(100 \mathrm{U} / \mathrm{ml})$ and penicillin $(100 \mathrm{U} / \mathrm{ml})$, and subjected to various treatment. PBS was used as negative control for both $\mathrm{VEGF}_{165}$ and IL-35. Supernatants were harvested for Ang2, IL-6, and IL-8 ELISA and MMP9 and MMP2 gel zymography analyses. All human sample collection procedures were approved by the Ethics Committee of the First Affiliated Hospital of China Medical University (Shenyang, China).

Ang2 ELISA

HUVECs and RA synovial tissue explants in 96-well plates were incubated with VEGF $165(20 \mathrm{ng} / \mathrm{ml})$ with or without IL-35 $(40 \mathrm{ng} / \mathrm{ml})$ for $18 \mathrm{~h}$. PBS was used as negative control for both VEGF ${ }_{165}$ and IL-35. The concentrations of Ang2 in the culture supernatants were determined using a human Ang2 Quantikine ELISA Kit from R\&D systems (Minneapolis, MN, USA). Absorbance at $450 \mathrm{~nm}$ was recorded on a microplate reader.

IL-6 and IL-8 ELISA

RA synovial tissue explants in 96-well plates were incubated with $20 \mathrm{ng} / \mathrm{ml} \mathrm{VEGF}_{165}, 200 \mathrm{ng} / \mathrm{ml}$ Ang2, and $40 \mathrm{ng} / \mathrm{ml} \mathrm{IL-35,} \mathrm{in} \mathrm{combination} \mathrm{or} \mathrm{alone} \mathrm{for} 18 \mathrm{~h}$. PBS was used as negative control for VEGF ${ }_{165}$, Ang2, and IL-35. The concentrations of IL- 6 and IL-8 in the culture supernatants were determined using human IL-6 [29] and IL-8 Quantikine ELISA Kits from R\&D systems, respectively.

MMP-2 and MMP-9 zymography

HUVECs and RA synovial tissue explants in 96-well plates were incubated with $20 \mathrm{ng} / \mathrm{ml} \mathrm{VEGF}_{165}, 200$ $\mathrm{ng} / \mathrm{ml}$ Ang2, and $40 \mathrm{ng} / \mathrm{ml} \mathrm{IL-35,} \mathrm{in} \mathrm{combination} \mathrm{or} \mathrm{alone} \mathrm{for} 18 \mathrm{~h}$. PBS was used as negative control for $\mathrm{VEGF}_{165}$, Ang2, and IL-35. The MMP-2 and MMP-9 activities in the culture supernatants were determined by gel zymography as previously described (cite reference of your choice). Briefly, supernatants $(10 \mu \mathrm{l})$ were separated by $10 \%$ SDS-PAGE with $1 \%$ gelatin under nonreducing conditions. The gels were washed with $2.5 \%$ Triton $\mathrm{X}-100$, incubated with substrate buffer at $37^{\circ} \mathrm{C}$ for $24 \mathrm{~h}$, and stained with Coomassie blue for 10 min. Gels were visualized using system UVP Biolmaging Systems (Upland, CA, USA).

Statistical analysis

All results are expressed as the mean \pm SD (standard deviation). Differences between groups were analyzed by the student's $t$-test or one-way analysis of variance (ANOVA). Statistical analysis was performed using SPSS 17.0 software (SPSS, Chicago, IL, USA). Statistical significance was defined as $\mathrm{P}<0.05$.

\section{Results}

IL-35 inhibits basal and VEGF-enhanced wound healing and chemotactic migration of HUVECS

We used the wound healing and Transwell migration assays to investigate the effects of IL-35 on EC migration in vitro. The results showed that IL-35 significantly inhibited basal 
HUVEC migration in these two assays (Fig. 1A, B). Compared with PBS control, VEGF ${ }_{165}(20$ $\mathrm{ng} / \mathrm{ml}$ ) significantly increased would healing and Transwell migration of HUVECs; these promigratory effects of $\mathrm{VEGF}_{165}$ were significantly attenuated by IL-35 in a dose dependently manner (Fig. 1A, B). Thus, IL-35 can repress both basal and VEGF-increased HUVEC motility and chemotaxis by directly acting on these cells.

\section{IL-35 inhibits basal and VEGF-enhanced HUVEC adhesion and tube formation}

Subsequently, we evaluated the effects of IL-35 on EC adhesion and tube formation in vitro. After $24 \mathrm{~h}$ incubation, HUVECs exhibited much stronger adhesion to FN-coated plates compared with BSA-coated plates (Fig. 2A). IL-35 dose-dependently inhibited basal HUVEC adhesion to FN-coated plates (Fig. 2A). VEGF ${ }_{165}$ at $20 \mathrm{ng} / \mathrm{ml}$ significantly enhanced HUVEC adhesion; this pro-adhesive effect of $\mathrm{VEGF}_{165}$ was significantly reduced by IL-35 in a dose dependent manner (Fig. 2A). Similarly, IL-35 dose-dependently inhibited both basal and $\mathrm{VEGF}_{165}$-enhanced formation of capillary-like structures by HUVECs seeded in Matrigelcoated plates (Fig. 2B). Therefore, in addition to motility and chemotaxis, IL-35 can directly repress both basal and VEGF-enhanced HUVEC adhesiveness and in vitro angiogenesis.

\section{IL-35 inhibits basal and VEGF-induced angiogenesis in vivo}

Finally, we examined the function of IL-35 in angiogenesis in vivo using the murine Matrigel plug model. In this assay, test compounds are loaded into liquid Matrigel which, after subcutaneous injection, solidifies and permits penetration by host cells and the formation of new blood vessels [30]. In this study, Matrigel containing $\mathrm{VEGF}_{165}(250 \mathrm{ng})$ and heparin

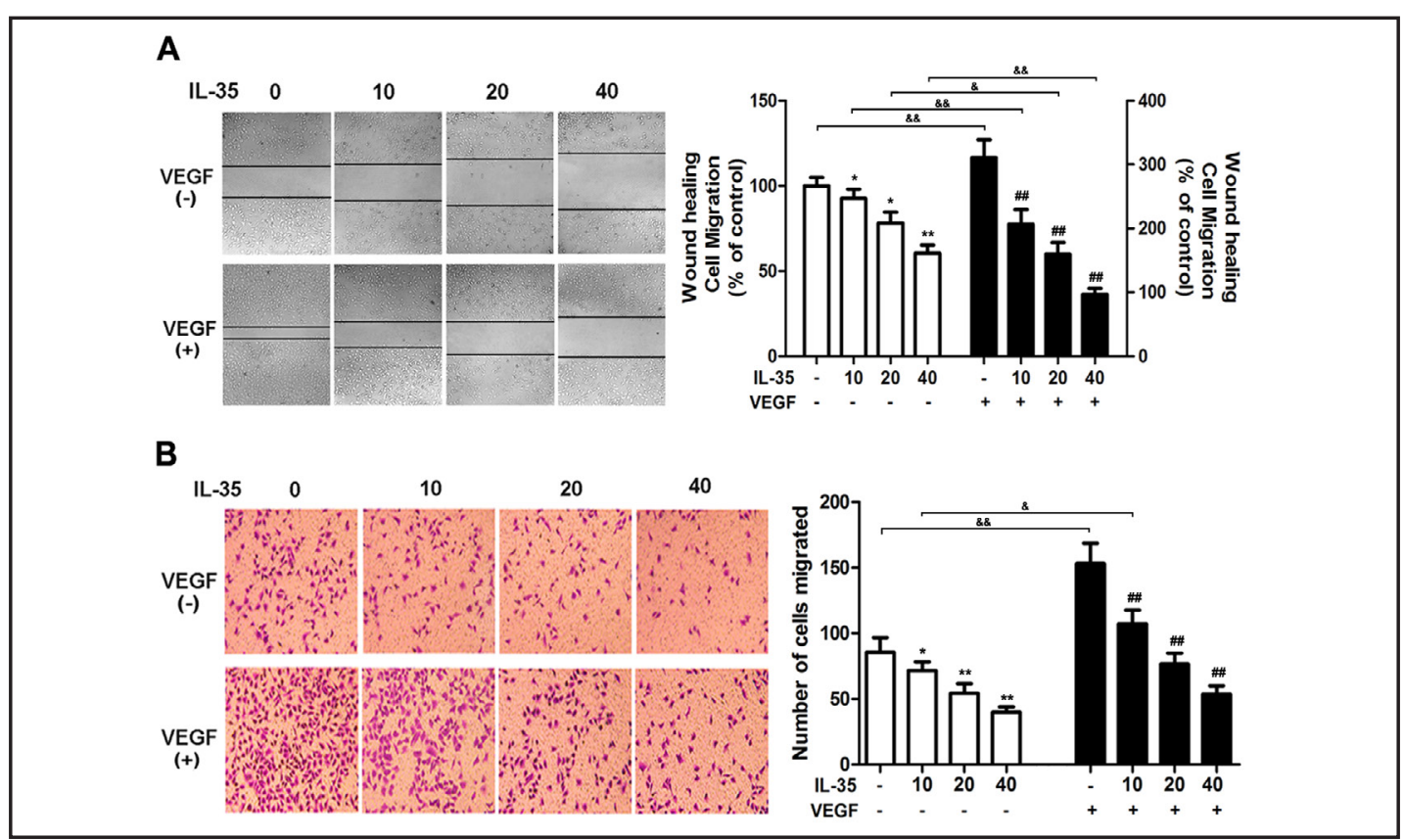

Fig. 1. IL-35 inhibits basal and $\mathrm{VEGF}_{165}$-induced HUVEC wound healing and chemotactic migration. (A) Wound healing migration assay. HUVECs were incubated with $20 \mathrm{ng} / \mathrm{ml} \mathrm{VEGF}_{165}$ and various concentrations of IL-35 (0-40 ng/ml). PBS was used as vehicle control for both VEGF ${ }_{165}$ and IL-35. Cell motility was determined by photography ( $\times 100$ magnification) $18 \mathrm{~h}$ after scratch wounding. (B) Chemotactic migration assay. $\operatorname{VEGF}_{165}(20 \mathrm{ng} / \mathrm{ml})$ was added to the lower Transwell chambers. PBS was used as vehicle control for VEGF ${ }_{165}$. HUVECs suspended in medium containing various concentrations of IL-35 (0-40 ng/ml) were loaded to the upper chambers and allowed to migrate for $4 \mathrm{~h}$. The number of cells that had migrated to the lower surface of the membrane was counted under a microscope $(\times 200$ magnification $)$ after hematoxylin and eosin staining. $\mathrm{n}=3 .{ }^{*} P<0.05,{ }^{* *} P<0.01$ vs. IL-35(-)/VEGF(-); ${ }^{\#} P<0.05,{ }^{\#} P<0.01$ vs. IL-35(-)/VEGF(+); ${ }^{\&} P<0.05$, ${ }^{\& \&} P<0.01$. 


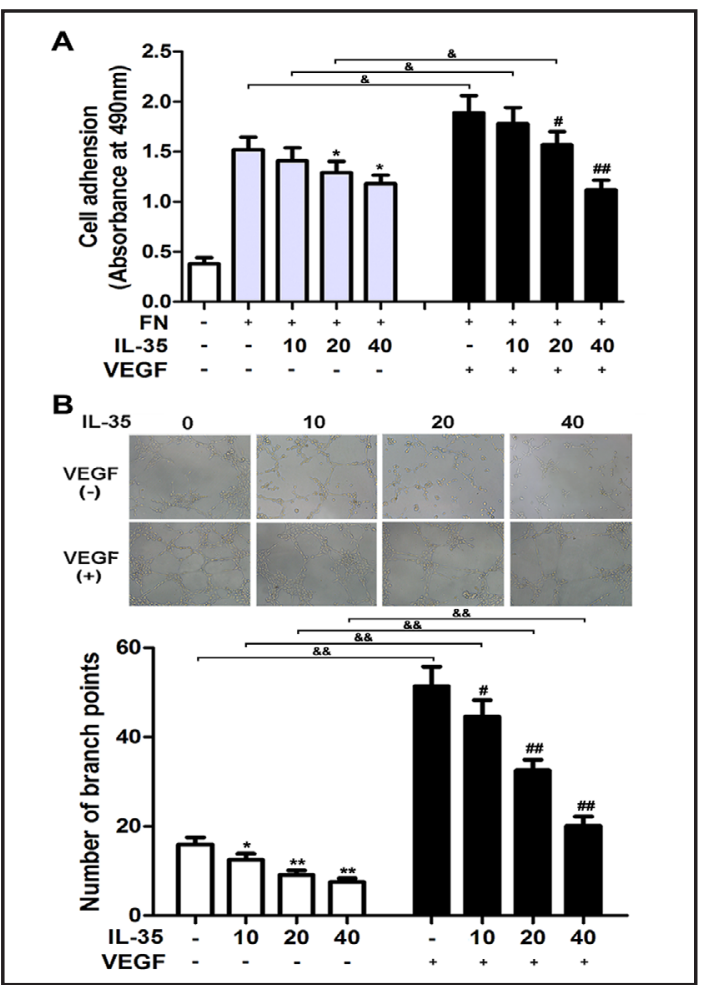

Fig. 2. IL-35 inhibits basal and $V_{E G F}$-induced HUVEC adhesion and tube formation. (A) Cell adhesion assay. HUVECs seeded in FN-coated plates were treated with $20 \mathrm{ng} / \mathrm{ml} \mathrm{VEGF}_{165}$ in the presence of various concentrations of IL-35 $(0-40 \mathrm{ng} / \mathrm{ml})$ for $24 \mathrm{~h}$. Cell adhesion was determined by the MTS assay. Cells seeded in BSA-coated plates were used as negative control. PBS was used as vehicle control for both VEGF ${ }_{165}$ and IL-35. $\mathrm{n}=3,{ }^{*} P<0.05,{ }^{* *} P<0.01$ vs. $\quad \mathrm{FN}(+) / \mathrm{IL}-35(-) / \operatorname{VEGF}(-) ; \quad{ }^{*} P<0.05, \quad{ }^{\# \#} P<0.01$ vs. $F N(+) / \operatorname{IL}-35(-) / \operatorname{VEGF}(+) ; \quad{ }^{\&} P<0.05$. (B) Tube formation assay. HUVECs seeded in Matrigel-coated plates were incubated with $20 \mathrm{ng} / \mathrm{ml} \mathrm{VEGF}_{165}$ in the presence of various concentrations of IL-35 (0-40 $\mathrm{ng} / \mathrm{ml}$ ) for $18 \mathrm{~h}$. PBS was used as vehicle control for both VEGF $_{165}$ and IL-35. The formation of capillarylike structures was analyzed by phase contrast microscopy. $\mathrm{n}=3 .{ }^{*} P<0.05,{ }^{* *} P<0.01$ vs. IL-35(-)/ $\operatorname{VEGF}(-) ; \quad{ }^{\#} P<0.05,{ }^{\# \#} P<0.01$ vs. IL-35(-)/VEGF(+);

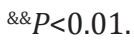

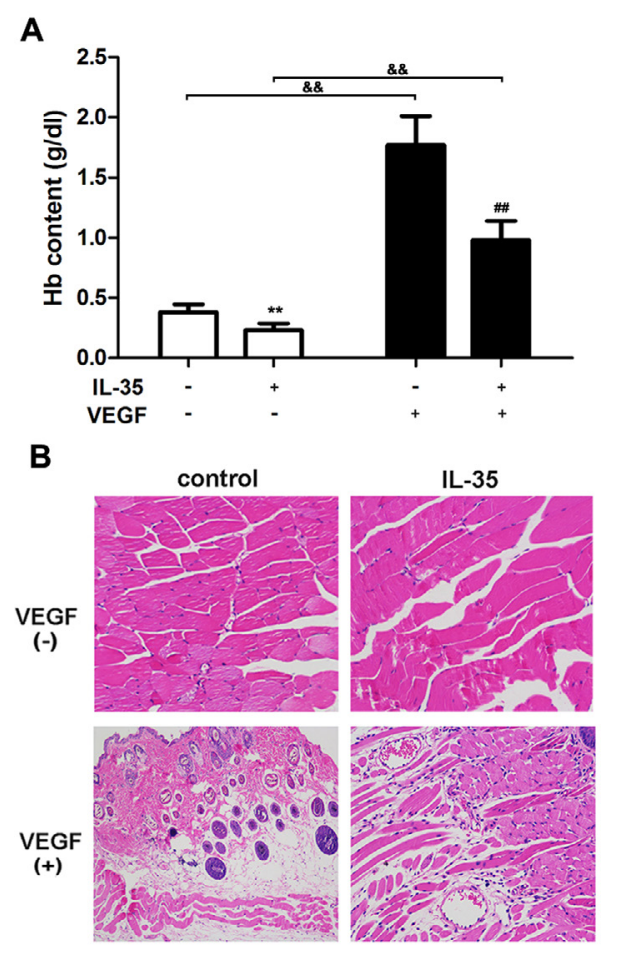

Fig. 3. IL-35 inhibits basal and $\mathrm{VEGF}_{165}$-induced blood vessel growth in Matrigel plugs in vivo. Matrigel containing $\mathrm{VEGF}_{165}$ (250 ng) and heparin (4.5 U) was subcutaneously injected with or without IL$35(2 \mu \mathrm{g})$ in mice. PBS was used as negative control for both VEGF ${ }_{165}$ and IL-35. Mice were sacrificed $14 \mathrm{~d}$ after the injection. (A) Hemoglobin levels in the Matrigel plugs measured by the Drabkin method. $\mathrm{n}=6$. ${ }^{* *} P<0.01$ vs. IL-35(-)/VEGF(-); ${ }^{\# \# ~} P<0.01$ vs. IL-35(-)/ $\operatorname{VEGF}(+) ;{ }^{\&} P<0.01$. (B) Representative photographs of the Matrigel plug sections stained with hematoxylin and eosin (200× magnification).

(4.5 U) was subcutaneously injected with or without IL-35 (2 $\mu \mathrm{g})$ in mice. PBS was used as negative control for VEGF ${ }_{165}$. After 14 days, angiogenesis was assessed by measuring the $\mathrm{Hb}$ content and by histological analysis of Matrigel plug section after hematoxylin and eosin staining. Consistent with our in vitro findings, IL-35 injection ( $2 \mu \mathrm{g})$ significantly reduced the $\mathrm{Hb}$ content of the Matrigel plugs (Fig. 3A). $\operatorname{VEGF}_{165}(0.25 \mu \mathrm{g})$ injection markedly increased the $\mathrm{Hb}$ content; this increase in $\mathrm{Hb}$ was significantly diminished by co-injection of IL-35 (2 $\mu \mathrm{g})$ (Fig. 3A). In alignment with these changes in Hb content, IL-35 visibly inhibited new blood vessel formation in the plugs under basal and VEGF ${ }_{165}$ treatment conditions (Fig. 3B), demonstrating the anti-angiogenic effects of IL-35 in vivo. 
Fig. 4. IL-35 inhibits Ang2, MMP, and inflammatory cytokine production. (A) HUVECs and RA synovial tissue explants were incubated with VEGF ${ }_{165}(20$ $\mathrm{ng} / \mathrm{ml}$ ) with or without IL-35 (40 ng/ $\mathrm{ml}$ ) for $18 \mathrm{~h}$. PBS was used as negative control for both VEGF 165 and IL-35. The concentrations of Ang2 in the culture media were determined by ELISA. $\mathrm{n}=3 .{ }^{*} P<0.05$ vs. IL-35(-)/VEGF(-); ${ }^{\#} P<0.05$ vs. IL-35(-)/VEGF $(+)$; ${ }^{\circledR} P<0.05$, $\& \& P<0.01$. (B) HUVECs and RA synovial tissue explants in 96-well plates were incubated with $20 \mathrm{ng} / \mathrm{ml} \mathrm{VEGF}_{165}, 200$ $\mathrm{ng} / \mathrm{ml}$ Ang2, and $40 \mathrm{ng} / \mathrm{ml} \mathrm{IL-35,} \mathrm{in}$ combination or alone for $18 \mathrm{~h}$. PBS was used as negative control for $\mathrm{VEGF}_{165}$, Ang2, and IL-35. The MMP-2 and MMP9 activities in the culture supernatants were determined by gel zymography. (C) RA synovial tissue explants in 96well plates were incubated with $20 \mathrm{ng} /$ $\mathrm{ml} \mathrm{VEGF}_{165}, 200 \mathrm{ng} / \mathrm{ml}$ Ang2, and $40 \mathrm{ng} /$ $\mathrm{ml}$ IL-35, in combination or alone for 18 h. PBS was used as negative control for $\mathrm{VEGF}_{165}$, Ang2, and IL-35. The concent-

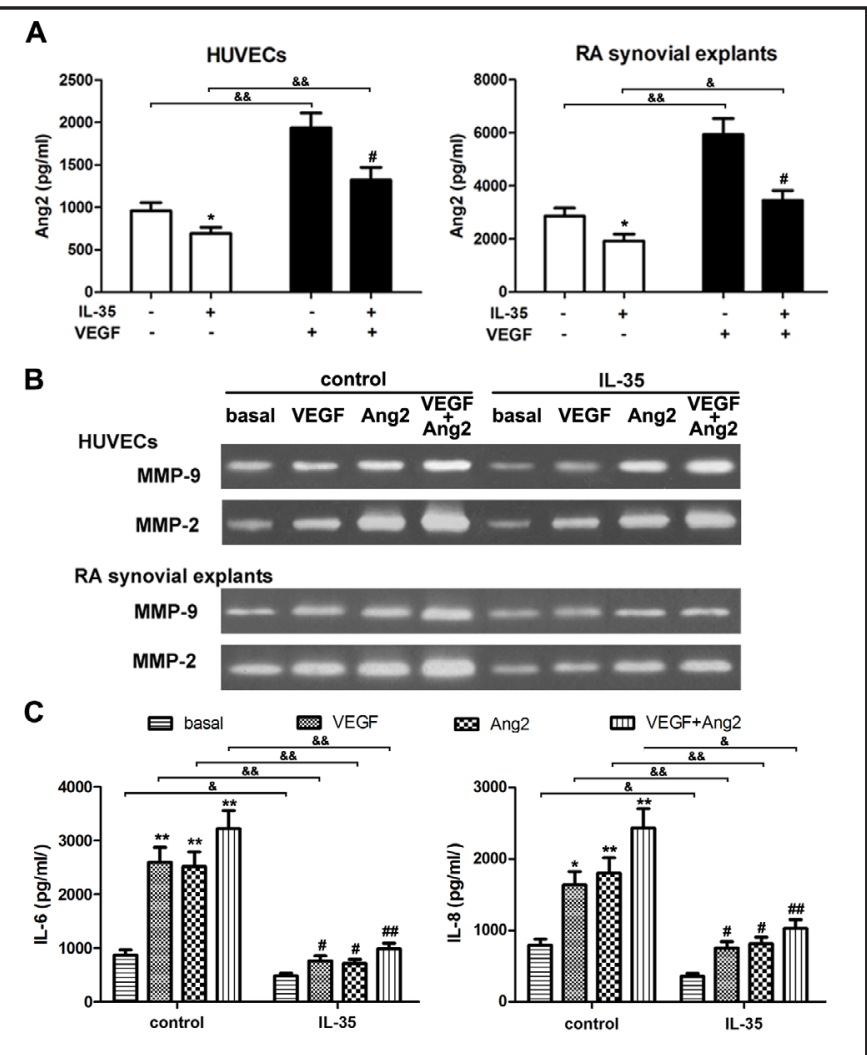
rations of IL- 6 and IL-8 in the culture supernatants were determined by ELISA. $\mathrm{n}=3 .{ }^{*} P<0.05,{ }^{* *} P<0.01$ vs.

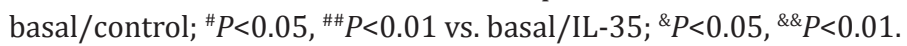

IL-35 inhibits Ang2, MMP, and cytokine production by HUVEC and RA synovial tissue explants

Previous studies have shown that tumor-derived VEGF drives Ang2 expression in host stroma endothelial cells, and VEGF directly up-regulates Ang2 in cultured endothelial cells via the VEGF receptor-2/flk-1/KDR pathway; thus, the autocrine regulation of Ang2 by VEGF likely plays an important role in the VEGF-Ang cooperation in tumor angiogenesis in vivo [31]. In this study, we found that $\mathrm{VEGF}_{165}$ at $20 \mathrm{ng} / \mathrm{ml}$ significantly increased Ang2 protein secretion by both HUVECs and RA synovial tissue explants after $18 \mathrm{~h}$ incubation (Fig 4A). These results indicated that VEGF likely exerts its proangiogenic effects in RA synovia at least partially through upregulation of Ang2. Interestingly, IL-35 (40 ng/ml) inhibited Ang2 secretion by HUVECs and RA synovial explants under both basal and VEGF treatment conditions (Fig 4A), suggesting that the anti-angiogenic effects of IL-35 in vitro and in vivo might be mediated through Ang2 downregulation. Moreover, treatment with exogenous $\mathrm{VEGF}_{165}$ and Ang2, alone or in combination, significantly increased MMP2 and MMP9 activities in the culture supernatants of HUVECs and RA synovial explants (Fig. 4B). $\mathrm{VEGF}_{165}$ and Ang2, alone or in combination, also enhanced IL- 6 and IL-8 secretion by RA synovial explants (Fig. 4C). Synergistic effects were observed between these two factors (Fig. 4B, C). Thus, in addition to its proangiogenic effects, VEGF can contribute to RA synovial inflammation at least partially through upregulation of Ang2. IL-35 decreased MMP2/ MMP9 activities and IL-6/IL-8 concentrations either under basal conditions or with VEGF/ Ang2 treatment, alone or in combination (Fig. 4B, C), suggesting that IL-35 can suppress RA inflammation through regulation of the VEGF/Ang2 crosstalk. 


\section{Cellular Physiology Cell Physiol Biochem 2016;40:1105-1116 \begin{tabular}{ll|l} 
DOI: 10.1159/000453165 & $\begin{array}{l}\text { O 2016 The Author(s). Published by S. Karger AG, Basel } \\
\text { www.karger.com/cpb }\end{array}$
\end{tabular} \\ Jiang et al.: The Inhibitory Role of IL-35 in Angiogenesis}

Fig. 5. IL-35 inhibits $\mathrm{VEGF}_{165}$-induced HUVEC wound healing, chemotactic migration, cell adhesion and tube formation through the Ang2/Tie2 pathway. (A) Wound healing migration assay. HUVECs were incubated with $20 \mathrm{ng} / \mathrm{ml} \mathrm{VEGF}_{165}, 200 \mathrm{ng} /$ $\mathrm{ml}$ Ang2, $40 \mathrm{ng} / \mathrm{ml} \mathrm{IL-35,} \mathrm{and}$ $10 \mu \mathrm{g} / \mathrm{ml}$ anti-Tie2 or anti-IgG, either alone or in combination as indicated. Cell motility was determined by photography ( $\times 100$ magnification) $18 \mathrm{~h}$ after scratch wounding. (B) Chemotactic migration assay. $\mathrm{VEGF}_{165}$ (20 ng/ml) and Ang2 (200 ng/ $\mathrm{ml}$ ), in combination or alone was added to the lower Transwell chambers. HUVECs suspended in medium containing IL-35 (40 $\mathrm{ng} / \mathrm{ml})$, anti-Tie2 $(10 \mu \mathrm{g} / \mathrm{ml})$, or anti-IgG $(10 \mu \mathrm{g} / \mathrm{ml})$ were loaded to the upper chambers and allowed to migrate for $4 \mathrm{~h}$. The number of cells that had migrated to the lower surface of the membrane was counted under a microscopy ( $\times 200$ magnification) after hematoxylin and eosin staining. (C) Cell adhesion assay. HUVECs seeded in FN-coated plates were treated with $20 \mathrm{ng} /$ $\mathrm{ml} \mathrm{VEGF}{ }_{165}, 200 \mathrm{ng} / \mathrm{ml}$ Ang2, 40 $\mathrm{ng} / \mathrm{ml} \mathrm{IL-35,} \mathrm{and} 10 \mu \mathrm{g} / \mathrm{ml}$ anti-Tie2 or anti-IgG, either alone or in combination as indicated for $24 \mathrm{~h}$. Cell adhesion was determined by the MTS assay. (D)
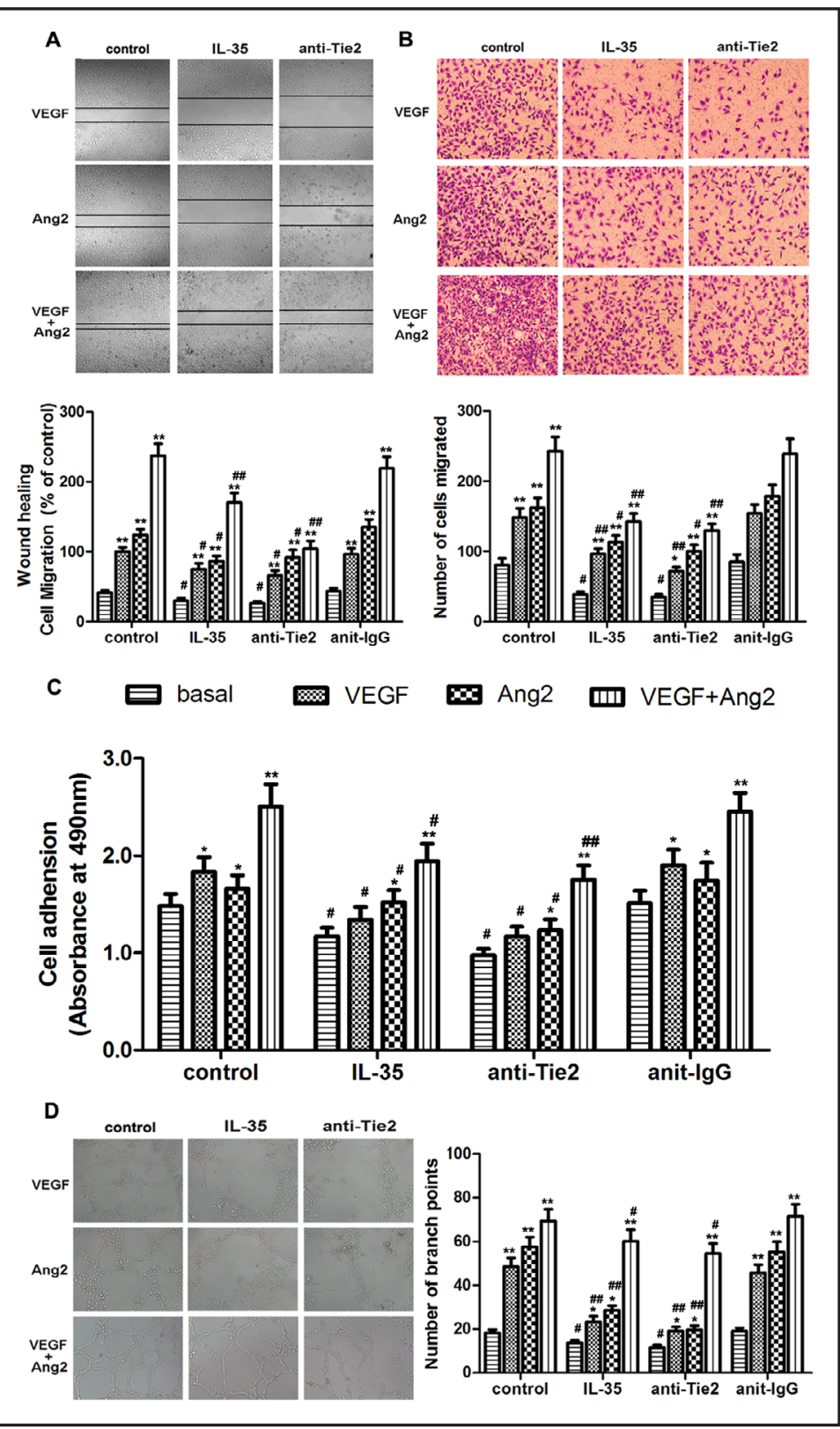

Tube formation assay. HUVECs seeded in Matrigel-coated plates were incubated with $20 \mathrm{ng} / \mathrm{ml} \mathrm{VEGF}{ }_{165}$, $200 \mathrm{ng} / \mathrm{ml}$ Ang2, $40 \mathrm{ng} / \mathrm{ml} \mathrm{IL-35}$, and $10 \mu \mathrm{g} / \mathrm{ml}$ anti-Tie2 or anti-IgG, either alone or in combination as indicated for $18 \mathrm{~h}$. The formation of capillary-like structures was analyzed by phase contrast microscopy. $\mathrm{n}=3$. ${ }^{*} P<0.05,{ }^{* *} P<0.01$ vs. basal; ${ }^{\#} P<0.05,{ }^{\# *} P<0.01$ vs. control.

IL-35 restrains VEGF-induced HUVEC migration, adhesion, and tube formation via the Ang2/Tie2 pathway

To confirm the involvement of the Ang2/Tie2 pathway in the proangiogenic effects of VEGF, we tested the effects of exogenous Ang2 and a Tie2 kinase antibody (anti-Tie2) that blocks the Ang/Tie2 signaling. Similar to $\mathrm{VEGF}_{165}$, Ang2 (200 ng/ml) enhanced HUVEC would healing migration, chemotaxis, adhesion, and tube formation; and synergistic effects were observed between the two factors (Fig. 5A-D). Anti-Tie2 $(10 \mu \mathrm{g} / \mathrm{ml})$ inhibited the proangiogenic effects of not only Ang2, but also $\mathrm{VEGF}_{165}$ (Fig. 5A-D), confirming that $\mathrm{VEGF}_{165}$ exerts its proangiogenic effects by increasing the Ang2/Tie2 signaling. Interestingly, the 
proangiogenic effects of VEGF/Ang2 (alone or in combination) in HUVECs were effectively blocked by IL-35 (Fig. 5A-D), suggesting that IL-35 restrains VEGF-induced angiogenesis not only by inhibiting Ang2 expression, but also by suppressing Ang2/Tie2 signal transduction.

\section{Discussion}

Persistent angiogenesis supports delivery of nutrients and inflammatory cells to the RA synovia to maintain chronic architectural changes and foster inflammation [32]. Numerous compounds that exhibit anti-rheumatic activities [33], e.g., interleukins, antibodies against angiogenic factors, and disease-modifying anti-rheumatic drugs, have been found to have anti-angiogenic properties. Emerging evidence implicates that targeting synovial angiogenesis may provide a promising therapeutic approach for RA [34]. Although a broad spectrum of molecules are involved in regulation of angiogenesis, VEGF and Angs, the only known growth factors largely specific for vascular endothelial cells, have been proposed to play a predominant role in neovascularization in RA pathology [35]. In experimental CIA models, VEGF expression is higher in synovial tissues [6, 36], and correlates with synovial neovascularization and disease severity [37]. Administration of anti-VEGF antiserum before, but not after the onset of the disease delays arthritis progression, suggesting that VEGF plays a critical role in early disease development [37]. Ang2 has been implicated in hypoxia-driven synovial angiogenesis in patients with inflammatory arthritis [38]. Gene therapy against the Ang receptor Tie2 before and after disease onset attenuates severity of arthritis [15]. These findings underscore the potential value of targeting these proangiogenic factors in RA treatment.

Although the cooperation between VEGF and Angs play a critical role in both developmental and pathogenic vascularization, mechanisms regulating the coordinated expression of these molecules remain largely unknown. Studies have shown that VEGF directly upregulates Ang2 in cultured endothelial cells in vitro [31, 39], and tumor-derived VEGF induces Ang2 expression in host stroma endothelial cells in vivo [31]. In this study, we found that VEGF significantly induced Ang2 expression in HUVECs in vitro and in RA synovial tissue explants ex vivo. Exogenous Ang2 promoted HUVEC migration, adhesion, and tube formation with similar potency to VEGF. Blocking the Ang/Tie2 pathway with a Tie2 kinase antibody inhibited the proangiogenic effect of both Ang2 and VEGF in HUVECs. Taken together, these results suggested that VEGF promotes angiogenesis in RA synovial tissues at least partially by upregulating Ang2. This autocrine VEGF/Ang2 crosstalk likely contributes to coordinated actions of these two molecules to drive RA synovial angiogenesis.

In this study, we found that the anti-inflammatory cytokine IL-35 also exhibited strong anti-angiogenic properties. IL-35 significantly decreased both basal and VEGF-induced HUVEC migration and adhesion in vitro as well as tube formation in vitro and in vivo. Our data showed that IL-35 inhibited both basal and VEGF-induced Ang2 expression in HUVECs and in RA synovial tissue explants. Interestingly, IL-35 also antagonized the proangiogenic effects of exogenous Ang2 in HUVECs. These results suggested that IL-35 restrains basal and VEGFinduced angiogenesis by inhibiting Ang2 expression as well as disrupting Ang2/Tie2 signal transduction. Moreover, we found that exogenous VEGF and Ang2 (alone or combination) increased the secretion of MMP2 and MMP9 as well as the inflammatory cytokines IL-6 and IL-8 by HUVECs and RA synovial explants. These results are somewhat in alignment with previous reports that Ang2 promotes inflammatory cytokine production by synovial macrophages [13]. In this study, IL-35 reduced MMP2, MMP9, IL-6, and IL-8 secretion either under basal conditions or with VEGF/Ang2 treatment (alone or in combination), suggesting that IL-35 can curb RA inflammation via regulation of the VEGF/Ang2 crosstalk.

Evidence suggests that the Notch pathway is involved in the proangiogenic effects of VEGF and Ang2 in RA synovial tissues [40]. Meanwhile, the pro-inflammatory effects of Ang2 in RA have been reported to be mediated through NF- $\kappa B$, MEK/ERK, Akt, JNK, and p38 [13]. IL-35 signaling requires the transcription factors STAT1 and STAT4 [18]. Thus, the IL-

\section{KARGER}




\section{Cellular Physiology Cell Physiol Biochem 2016;40:1105-1116 \begin{tabular}{l|l|l|}
\hline DOI: 10.1159/000453165 & $\begin{array}{l}\text { C } 2016 \text { The Author(s). Published by S. Karger AG, Basel } \\
\text { www.karger.com/cpb }\end{array}$ \\
\hline
\end{tabular} \\ Jiang et al.: The Inhibitory Role of IL-35 in Angiogenesis}

35, VEGF, and Ang2 crosstalk involved in RA angiogenesis and inflammation likely engages the interplay of these signaling cascades. In this study, VEGF and Ang2 showed synergetic effects; thus the molecular mechanisms involved in their actions may not be precisely the same. The precise mechanisms involved require further investigation. Previous studies have shown that IL-35 subdues arthritis progression through the stimulation of regulatory $\mathrm{T}$ cells, suppression of Th17 cells, and induction of IL-10 [22, 23]. Our findings in this study suggested that IL-35 might delay RA progression by disrupting synovial neovascularization and inflammation through regulation of the VEGF/Ang2 crosstalk. RA angiogenesis and inflammation are controlled by many factors that are in crosstalk with each other. Targeting a single player may not be sufficient to impact disease progression. IL-35 may provide an effective therapy for RA since it antagonizes VEGF and Ang2, the two important driving factors in RA.

\section{Acknowledgements}

The study was funded by the Natural Science Foundation of China (No. 81172867).

\section{Disclosure Statement} article.

The authors declare that they have no conflicts of interest with the contents of this

\section{References}

1 Elshabrawy HA, Chen Z, Volin MV, Ravella S, Virupannavar S, Shahrara S: The pathogenic role of angiogenesis in rheumatoid arthritis. Angiogenesis 2015;18:433-448.

2 Szekanecz Z, Besenyei T, Szentpetery A, Koch AE: Angiogenesis and vasculogenesis in rheumatoid arthritis. Curr Opin Rheumatol 2010;22:299-306.

3 Nagashima M, Yoshino S, Ishiwata T, Asano G: Role of vascular endothelial growth factor in angiogenesis of rheumatoid arthritis. J Rheumatol 1995;22:1624-1630.

4 Maruotti N, Cantatore FP, Crivellato E, Vacca A, Ribatti D: Angiogenesis in rheumatoid arthritis. Histol Histopathol 2006;21:557-566.

5 Kayakabe K, Kuroiwa T, Sakurai N, Ikeuchi H, Kadiombo AT, Sakairi T, Matsumoto T, Maeshima A, Hiromura K, Nojima Y: Interleukin- 6 promotes destabilized angiogenesis by modulating angiopoietin expression in rheumatoid arthritis. Rheumatology (Oxford) 2012;51:1571-1579.

6 Clavel G, Bessis N, Boissier MC: Recent data on the role for angiogenesis in rheumatoid arthritis. Joint Bone Spine 2003;70:321-326.

7 Marrelli A, Cipriani P, Liakouli V, Carubbi F, Perricone C, Perricone R, Giacomelli R: Angiogenesis in rheumatoid arthritis: a disease specific process or a common response to chronic inflammation? Autoimmun Rev 2011;10:595-598.

8 Morisada T, Kubota Y, Urano T, Suda T, Oike Y: Angiopoietins and angiopoietin-like proteins in angiogenesis. Endothelium 2006;13:71-79.

9 Kobayashi H, Lin PC: Angiopoietin/Tie2 signaling, tumor angiogenesis and inflammatory diseases. Front Biosci 2005;10:666-674.

10 Shahrara S, Volin MV, Connors MA, Haines GK, Koch AE: Differential expression of the angiogenic Tie receptor family in arthritic and normal synovial tissue. Arthritis Res 2002;4:201-208.

11 DeBusk LM, Chen Y, Nishishita T, Chen J, Thomas JW, Lin PC: Tie2 receptor tyrosine kinase, a major mediator of tumor necrosis factor alpha-induced angiogenesis in rheumatoid arthritis. Arthritis Rheum 2003;48:2461-2471. 


\section{Cellular Physiology Cell Physiol Biochem 2016;40:1105-1116

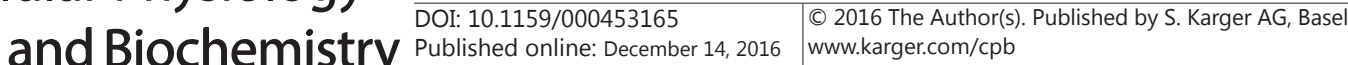

Jiang et al.: The Inhibitory Role of IL-35 in Angiogenesis

12 Saber T, Veale DJ, Balogh E, McCormick J, NicAnUltaigh S, Connolly M, Fearon U: Toll-like receptor 2 induced angiogenesis and invasion is mediated through the Tie2 signalling pathway in rheumatoid arthritis. PLoS One 2011;6:e23540.

13 Krausz S, Garcia S, Ambarus CA, de Launay D, Foster M, Naiman B, Iverson W, Connor JR, Sleeman MA, Coyle AJ, Hamann J, Baeten D, Tak PP, Reedquist KA: Angiopoietin-2 promotes inflammatory activation of human macrophages and is essential for murine experimental arthritis. Ann Rheum Dis 2012;71:1402-1410.

14 van de Sande MG, de Launay D, de Hair MJ, Garcia S, van de Sande GP, Wijbrandts CA, Gerlag DM, Reedquist KA, Tak PP: Local synovial engagement of angiogenic TIE-2 is associated with the development of persistent erosive rheumatoid arthritis in patients with early arthritis. Arthritis Rheum 2013;65:30733083.

15 Chen Y, Donnelly E, Kobayashi H, Debusk LM, Lin PC: Gene therapy targeting the Tie2 function ameliorates collagen-induced arthritis and protects against bone destruction. Arthritis Rheum 2005;52:1585-1594.

16 Collison LW, Workman CJ, Kuo TT, Boyd K, Wang Y, Vignali KM, Cross R, Sehy D, Blumberg RS, Vignali DA: The inhibitory cytokine IL-35 contributes to regulatory T-cell function. Nature 2007;450:566-569.

17 Collison LW, Vignali DA: Interleukin-35: odd one out or part of the family? Immunol Rev 2008;226:248262.

18 Collison LW, Delgoffe GM, Guy CS, Vignali KM, Chaturvedi V, Fairweather D, Satoskar AR, Garcia KC, Hunter CA, Drake CG, Murray PJ, Vignali DA: The composition and signaling of the IL-35 receptor are unconventional. Nat Immunol 2012;13:290-299.

19 Chaturvedi V, Collison LW, Guy CS, Workman CJ, Vignali DA: Cutting edge: Human regulatory T cells require IL-35 to mediate suppression and infectious tolerance. J Immunol 2011;186:6661-6666.

20 Castellani ML, Anogeianaki A, Felaco P, Toniato E, De Lutiis MA, Shaik B, Fulcheri M, Vecchiet J, Tete S, Salini V, Theoharides TC, Caraffa A, Antinolfi P, Frydas I, Conti P, Cuccurullo C, Ciampoli C, Cerulli G, Kempuraj D: IL-35, an anti-inflammatory cytokine which expands CD4+CD25+ Treg Cells. J Biol Regul Homeost Agents 2010;24:131-135.

21 Li X, Mai J, Virtue A, Yin Y, Gong R, Sha X, Gutchigian S, Frisch A, Hodge I, Jiang X, Wang H, Yang XF: IL-35 is a novel responsive anti-inflammatory cytokine--a new system of categorizing anti-inflammatory cytokines. PLoS One 2012; 7:e33628.

22 Niedbala W, Wei XQ, Cai B, Hueber AJ, Leung BP, McInnes IB, Liew FY: IL-35 is a novel cytokine with therapeutic effects against collagen-induced arthritis through the expansion of regulatory $\mathrm{T}$ cells and suppression of Th17 cells. Eur J Immunol 2007;37:3021-3029.

23 Kochetkova I, Golden S, Holderness K, Callis G, Pascual DW: IL-35 stimulation of CD39+ regulatory T cells confers protection against collagen II-induced arthritis via the production of IL-10. J Immunol 2010;184:7144-7153.

24 Whitehead GS, Wilson RH, Nakano K, Burch LH, Nakano H, Cook DN: IL-35 production by inducible costimulator (ICOS)-positive regulatory T cells reverses established IL-17-dependent allergic airways disease. J Allergy Clin Immunol 2012;129:207-215 e201-205.

25 Sha X, Meng S, Li X, Xi H, Maddaloni M, Pascual DW, Shan H, Jiang X, Wang H, Yang XF: Interleukin-35 Inhibits Endothelial Cell Activation by Suppressing MAPK-AP-1 Pathway. J Biol Chem 2015;290:1930719318.

26 Wang Z, Liu JQ, Liu Z, Shen R, Zhang G, Xu J, Basu S, Feng Y, Bai XF: Tumor-derived IL-35 promotes tumor growth by enhancing myeloid cell accumulation and angiogenesis. J Immunol 2013;190:2415-2423.

27 Liu C, Kong X, Li X, Guo W, Zhang C, Sun Y, Su X, Liu X, Lu A, Lin N: Wen Luo Yin inhibits angiogenesis in collagen-induced arthritis rat model and in vitro. J Ethnopharmacol 2013;149:478-489.

28 Fearon U, Mullan R, Markham T, Connolly M, Sullivan S, Poole AR, FitzGerald O, Bresnihan B, Veale DJ: Oncostatin $\mathrm{M}$ induces angiogenesis and cartilage degradation in rheumatoid arthritis synovial tissue and human cartilage cocultures. Arthritis Rheum 2006;54:3152-3162.

29 Xu D, Yan S, Wang H, Gu B, Sun K, Yang X, Sun B, Wang X: IL-29 Enhances LPS/TLR4-Mediated Inflammation in Rheumatoid Arthritis. Cell Physiol Biochem 2015;37:27-34.

30 Akhtar N, Dickerson EB, Auerbach R: The sponge/Matrigel angiogenesis assay. Angiogenesis 2002;5:75-80.

31 Zhang L, Yang N, Park JW, Katsaros D, Fracchioli S, Cao G, O'Brien-Jenkins A, Randall TC, Rubin SC, Coukos G: Tumor-derived vascular endothelial growth factor up-regulates angiopoietin-2 in host endothelium and destabilizes host vasculature, supporting angiogenesis in ovarian cancer. Cancer Res 2003;63:3403-3412. 


\section{Cellular Physiology Cell Physiol Biochem 2016;40:1105-1116 \begin{tabular}{ll|ll} 
DOI: 10.1159/000453165 & O 2016 The Author(s). Published by S. Karger AG, Basel \\
and Biocherger.com/cpb
\end{tabular} \\ Jiang et al.: The Inhibitory Role of IL-35 in Angiogenesis}

32 Firestein GS: Starving the synovium: angiogenesis and inflammation in rheumatoid arthritis. J Clin Invest 1999;103:3-4.

33 Yan C, Kong D, Ge D, Zhang Y, Zhang X, Su C, Cao X: Mitomycin C induces apoptosis in rheumatoid arthritis fibroblast-like synoviocytes via a mitochondrial-mediated pathway. Cell Physiol Biochem 2015;35:11251136.

34 Maruotti N, Cantatore FP, Ribatti D: Putative effects of potentially anti-angiogenic drugs in rheumatic diseases. Eur J Clin Pharmacol 2014;70:135-140.

35 Carmeliet P, Jain RK: Angiogenesis in cancer and other diseases. Nature 2000;407:249-257.

36 Wu S, Li Y, Li Y, Yao L, Lin T, Jiang S, Shen H, Xia L, Lu J: Interleukin-35 attenuates collagen-induced arthritis through suppression of vascular endothelial growth factor and its receptors. Int Immunopharmacol 2016;34:71-77.

37 Lu J, Kasama T, Kobayashi K, Yoda Y, Shiozawa F, Hanyuda M, Negishi M, Ide H, Adachi M: Vascular endothelial growth factor expression and regulation of murine collagen-induced arthritis. J Immunol 2000;164:5922-5927.

38 Biniecka M, Connolly M, Gao W, Ng CT, Balogh E, Gogarty M, Santos L, Murphy E, Brayden D, Veale DJ, Fearon U: Redox-mediated angiogenesis in the hypoxic joint of inflammatory arthritis. Arthritis Rheumatol 2014;66:3300-3310.

39 Oh H, Takagi H, Suzuma K, Otani A, Matsumura M, Honda Y: Hypoxia and vascular endothelial growth factor selectively up-regulate angiopoietin-2 in bovine microvascular endothelial cells. J Biol Chem 1999;274:15732-15739.

40 Gao W, Sweeney C, Walsh C, Rooney P, McCormick J, Veale DJ, Fearon U: Notch signalling pathways mediate synovial angiogenesis in response to vascular endothelial growth factor and angiopoietin 2 . Ann Rheum Dis 2013;72:1080-1088. 